\title{
Diel cycles of isoprenoids in the emissions of Norway spruce, four Scots pine chemotypes, and in Boreal forest ambient air during HUMPPA-COPEC-2010
}

\author{
N. Yassaa ${ }^{1,2}$, W. Song ${ }^{1}$, J. Lelieveld ${ }^{1}$, A. Vanhatalo ${ }^{3}$, J. Bäck ${ }^{3}$, and J. Williams ${ }^{1}$ \\ ${ }^{1}$ Department of Air Chemistry, Max-Planck Institute for Chemistry, Mainz, Germany \\ ${ }^{2}$ USTHB, University of Sciences and Technology Houari Boumediene, Faculty of Chemistry, BP 32 El-Alia Bab-Ezzouar, \\ 16111Algiers, Algeria \\ ${ }^{3}$ Department of Forest Sciences, University of Helsinki, Finland
}

Correspondence to: N. Yassaa (nyassaa@usthb.dz)

Received: 3 April 2012 - Published in Atmos. Chem. Phys. Discuss.: 20 April 2012

Revised: 24 July 2012 - Accepted: 24 July 2012 - Published: 7 August 2012

\begin{abstract}
Branch enclosure based emission rates of monoterpenes and sesquiterpenes from four Scots pines $(P i$ nus sylvestris) and one Norway spruce (Picea abies), as well as the ambient mixing ratios of monoterpenes were determined during the HUMPPA-COPEC 2010 summer campaign. Differences in chemical composition and in emission strength were observed between the different trees, which confirmed that they represented different chemotypes. The chemotypes of Scots pine can be classified according to species with high, no and intermediate content of $\Delta-3$ carene. The "non- $\Delta-3$-carene" chemotype was found to be the strongest emitter of monoterpenes. From this chemotype, $\beta$-myrcene, a very reactive monoterpene, was the dominant species accounting for more than $32 \%$ of the total emission rates of isoprenoids followed by $\beta$-phellandrene $(\sim 27 \%)$. Myrcene fluxes ranged from 0.8 to $24 \mu \mathrm{gg}^{-1}(\mathrm{dw}) \mathrm{h}^{-1}$. $\alpha$ Farnesene was the dominant sesquiterpene species, with average emission rates of $318 \mathrm{ng} \mathrm{g}^{-1}(\mathrm{dw}) \mathrm{h}^{-1}$. In the high $\Delta$ 3 -carene chemotype, more than $48 \%$ of the total monoterpene emission was $\Delta$-3-carene. The average $\Delta$-3-carene emission rate (from chemotype 3 ), circa $609 \mathrm{ng} \mathrm{g}^{-1}(\mathrm{dw}) \mathrm{h}^{-1}$ reported here is consistent with the previously reported summer season value. Daily maximum temperatures varied between 20 and $35^{\circ} \mathrm{C}$ during the measurements. The monoterpene emissions from spruce were dominated by limonene (35\%), $\beta$-phellandrene (15\%), $\alpha$-pinene (14\%) and eucalyptol $(9 \%)$. Total spruce monoterpene emissions ranged from 0.55 up to $12.2 \mu \mathrm{gg}^{-1}(\mathrm{dw}) \mathrm{h}^{-1}$. Overall the
\end{abstract}

total terpene flux (monoterpenes + sesquiterpenes) from all studied tree species varied from $230 \mathrm{ng} \mathrm{g}^{-1}(\mathrm{dw}) \mathrm{h}^{-1}$ up to $66 \mu \mathrm{g} \mathrm{g}^{-1}(\mathrm{dw}) \mathrm{h}^{-1}$. Total ambient monoterpenes (including $\alpha$-pinene, $\Delta$-3-carene, $\beta$-pinene and $\beta$-myrcene) measured during the campaign varied in mixing ratio from a few pptv to over one ppbv. The most abundant biogenic VOC measured above the canopy were $\alpha$-pinene and $\Delta$-3-carene, and these two compounds together contributed more than $50 \%$ of the total monoterpenes. The ambient data reflect the emission rate, atmospheric reactivity and tree type abundance. The diel cycles of isoprenoid mixing ratios showed high levels during the night-time which is consistent with continued low nocturnal emission and a low and stable boundary layer. The chirality of $\alpha$-pinene was dominated by (+)-enantiomers both in the direct emission and in the atmosphere. The two highest emitters showed no enantiomeric preference for $\alpha$-pinene emissions, whereas the two lowest emitting pines emitted more (+)-enantiomer. The spruce emissions were dominated by (-)-enantiomer. The exceptionally hot temperatures in the summer of 2010 led to relatively strong emissions of monoterpenes, greater diversity in chemical composition and high ambient mixing ratios.

\section{Introduction}

Biogenic Volatile Organic Compounds (BVOC) are important constituents of the troposphere. They may influence the 
global oxidation capacity through reaction with $\mathrm{OH}$ and $\mathrm{O}_{3}$ (Atkinson and Arey, 2003, Kaplan et al., 2006), and can affect the global radiation balance as their oxidation products lead to aerosol formation and growth (Claeys et al., 2004, Kulmala et al.,2004, Tunved et al., 2006). Boreal forests are a strong source of BVOC and consequently the coniferous trees that make up much of this ecosystem have been under intensive study for several decades. These coniferous trees are known to emit significant quantities of reactive organic trace gases (e.g. monoterpenes) to the atmosphere as a function of temperature and to a lesser extent light (Rinne et al. 2009 and references therein). The emissions of biogenic VOC are subject to diel and seasonal modulations in both chemical composition and rates of released chemicals (e.g. Hakola et al., 2006; Song et al. 2011). To date most intensive measurement campaigns from the Boreal forest have focused on springtime aerosol nucleation events, however, BVOC emissions which are driven primarily by light and temperature, maximize in summer. In this study our aim was to quantify the BVOC from the summertime boreal forest in terms of emission rate (as a function of tree species and chemotype), and in terms of ambient air composition. Such measurements are needed to better understand the impact of BVOC emitted from the vast Boreal forest on the chemistry and physics of the Earth's atmosphere.

Scots pine (Pinus sylvestris L.) is one of the most common tree species in the boreal forests of Northern Europe. Its monoterpene emissions have been intensively studied over the past decade (Janson, 1993; Rinne et al., 1999, 2000; Staudt et al. 2000; Janson and de Serves, 2001; Komenda and Koppmann, 2002). Lindfors and Laurila, 2000; Lindfors et al. (2000) published the first emission inventories for North European forests. Scots pine and Norway spruce (Picea abies L.) emit monoterpenes both as a function of temperature and as a function of light (Ghirardo et al., 2010 and references therein), the latter emission being made de novo when tree is sunlit. Species like aspen (Populus tremula L.) and Norway spruce also emit large amounts of isoprene (Janson and de Serves, 2001; Hakola et al., 2000) again as a function of light. It should be noted that in the boreal summer daylight extends for circa $18 \mathrm{~h}(\sim 04: 00-23: 00)$.

Most of the branch scale emission studies have focused on short-term emissions of monoterpenes (Janson, 1993; Janson et al., 2001; Rinne et al., 1999, 2000; Komenda and Koppmann, 2002) or on the seasonal variations (Hakola et al., 2006) from Scots pine. In several studies of Scots pine, $\Delta$ 3 -carene was identified as the major terpene making up more than $60 \%$ of the emissions measured. $\alpha$-and $\beta$-pinene and a suite of other mono-and sesquiterpenes were present at moderate or low fractions of the total emission.

It has been established previously that native Scots pine populations have high intra-specific genetic variation reflected in their monoterpene emission blend. Trees of the same species but with distinctly different chemical emission distributions are termed chemotypes. Such chemotypes have been examined and identified, mostly by emission analysis from the detached shoot or other organs of the plant (e.g. Thoss et al., 2007; Bäck et al., 2012).

Our aim was to compare mono- and sesquiterpene emissions from four Scots pine trees and one Norway spruce tree under field conditions during a mid-summer period, and to reveal if their chemotypic differences are also reflected in the emission strength, diel patterns and chirality of the main emitted compounds. The determination of terpene composition in the emission of multiple living Scots pine chemotypes is performed for the first time in this work. It should be noted that this study of the intra-specific variation for Scots pines was made in vivo, with minor disturbance to the plant functioning by using branch enclosures under field conditions.

In addition to direct characterization of isoprenoids from branch enclosures, in-situ measurements were also performed to determine diel cycles of monoterpene mixing ratios above the forest canopy. This enabled the comparisons between variations in the ambient concentrations and the enantiomeric ratios with emissions directly from specific tree sources.

\section{Experimental}

\subsection{Brief description of the campaign}

The HUMPPA-COPEC 2010 (Hyytiälä United Measurement of Photochemistry and Particles in Air - Comprehensive Organic Particle and Environmental Chemistry) campaign was focused on comprehensively characterizing the atmospheric physics and chemistry over a Boreal forest site in summertime (Williams et al., 2011). The measurements took place from 12 July to 12 August 2010 at the Boreal forest field station, SMEAR II (Station for Measuring Forest Ecosystem - Atmosphere Relations) in Hyytiälä, southern Finland $\left(61^{\circ} 51^{\prime} \mathrm{N}\right.$; Longitude $24^{\circ} 17^{\prime} \mathrm{E}, 181 \mathrm{~m}$ a.s.l.). As a part of the study SPME-GC-MSD and online TD-GC-MSD systems described below were used to characterize the enantiomeric and non-enantiomeric isoprenoids from direct plant emission and in ambient air $2 \mathrm{~m}$ above the forest canopy, respectively.

\subsection{Plant enclosure experiments}

The isoprenoid emission rates were measured from four different Scots pines (Pinus sylvestris) and a single Norway spruce (Picea abies). These tree species are the most abundant coniferous trees surrounding the SMEAR II measurement station located in the south Finland Boreal forest. The forest site is described in detail in Ilvesniemi et al. (2009). The emission rates were measured hourly over several full diel cycles. 


\subsubsection{Plant species and branch enclosure system}

The trees measured in this study were growing in a natural $50 \mathrm{yr}$ old forest environment, in which the tree height was between 14-22 $\mathrm{m}$. The samples were collected from Teflon branch cuvette enclosures set at a height of about $13 \mathrm{~m}$ on four branches belonging to four different chemotypes of $\mathrm{Pi}$ nus sylvestris L. (Scots pine) and one branch from Picea abies (Norway spruce).

Emission rates were determined using a dynamic flowthrough technique as described in Hakola et al (2006). The cylindrical Teflon enclosures $(4.5 \mathrm{~L}$ volume) were equipped with inlet and outlet ports, as well as an internal thermometer. The cover of the enclosures was made of transparent Teflon film. The photosynthetically active photon flux density (PPFD) was measured just above the enclosure. The flow through the enclosure was about $4 \mathrm{~L}$ per minute. Ozone was removed from the inlet air using $\mathrm{MnO}_{2}$-coated copper filter (Pollmann et al., 2005).

The summertime temperatures measured at the site during the campaign period (July-August 2010) were anomalously high $\left(T_{\max }=37.2, T_{\min }=10.1, T_{\mathrm{ave}}=20.0^{\circ} \mathrm{C}\right)$, (Williams et al., 2011).

\subsubsection{SPME sampling and GC-MSD analysis}

During the HUMPPA-COPEC 2010 campaign a recently developed method based on sampling with solid-phase microextraction and analysis with gas chromatography/mass spectrometry was used to quantify terpenoids (Yassaa et al., 2010). Briefly, the air from the plant cuvette enclosure was continuously flushed through a SPME sampling chamber (installed less than $2 \mathrm{~m}$ close to plant cuvette enclosure) consisting of a $5 \mathrm{~L}$ glass compartment fitted with a small septum (Sigma-Aldrich, Supelco, Germany) in the middle and two $0.64 \mathrm{~cm}(1 / 4 \mathrm{inch})$ glass ports (inlet and outlet) connected to Teflon stopcocks. After an initial flushing period (minimum time $60 \mathrm{~min}$ ) of the sampling chamber, the stopcocks were closed isolating the collected air. The terpenes were sampled from the glass chamber, by piercing the septum and exposing the SPME fibre ( $65 \mu \mathrm{m}$ DVB-PDMS fibre coating, Sigma-Aldrich, Supelco, Germany) to the equilibrated air for $20 \mathrm{~min}$. After SPME sampling, the system was again set to flush by re-opening the two stopcocks.

Immediately after SPME sampling, the SPME needle was introduced into the split/splitless injector of the gas chromatograph. A glass inlet liner with a narrow internal diameter $(0.75 \mathrm{~mm}$ I.D., Supelco) was used in order to improve the GC resolution and the peak shape. Desorption was achieved in splitless mode at $250^{\circ} \mathrm{C}$ for $5 \mathrm{~min}$. These settings were found to be sufficient for a quantitative desorption of all analytes studied. This was established by subjecting the analysed fibre to a second desorption and observing no carry-over peaks. The DVB-PDMS response for monoterpenes was calibrated under the same conditions in the glass SPME sam- pling chamber using a 16 compound VOC certified standard (National Physical Laboratory, Teddington Middlesex, UK) which included the separate enantiomers of several species in the range of $2 \mathrm{ppbv}$. It should be noted that the compressed gas standard cylinder was delivered by NPL directly to the field site at the start of the campaign thus minimising any stability issues. Moreover, stability tests carried out by NPL in the development of this standard on a range of monoterpenes revealed generally good stability with only sabinene showing unacceptable variation. Sesquiterpenes have been quantified by introducing known amounts of diluted pure liquid sesquiterpene standard in cyclohexane into the SPME sampling chamber, similarly to Bouvier-Brown et al. (2007). Prior to field use, the SPME method has extensively tested from plant chamber measurement of mono-and sesquiterpenes.

The analysis was conducted using the procedure described by Yassaa and Williams (2005, 2007). Briefly, samples were separated and detected using a gas chromatograph (Agilent Technologies a GC 6890A) coupled to a mass-selective detector (Agilent Technologies MSD 5973 inert). The MS system was operated in electron impact mode with the following conditions: ionization potential $70 \mathrm{eV}$; source temperature $230^{\circ} \mathrm{C}$. The MS system was operated in scan mode $(30-350 \mathrm{u})$ for the identification of compounds, and in selected ion monitoring (SIM) mode for their quantification. The enantiomeric and non-enantiomeric monoterpenes were separated using a Cyclodex-B capillary column (30 m long, $0.256 \mathrm{~mm}$ I.D., $0.25 \mu \mathrm{m}$ film thickness) supplied by J\&W Scientific (Folsom, CA, USA). The internal coating was composed of a permethylated $\beta$-cyclodextrin dissolved into a cyanopropyl-dimethyl polysiloxane liquid. At a constant helium carrier gas (Messer Griesheim 6.0) flow rate of $1 \mathrm{~mL} \mathrm{~min}^{-1}$, the column temperature was maintained at $40^{\circ} \mathrm{C}$ for $5 \mathrm{~min}$, then increased to $180^{\circ} \mathrm{C}$ at $1.5^{\circ} \mathrm{C}$ per minute as previously established by Yassaa et al. (2001).

To determine the terpenoid emission rates from each plant shoot, air samples were collected onto SPME fibre from both the inlet and outlet ports of the cuvette enclosure. The emission rate $(E)$ was determined as the mass of compound per needle dry weight and time $\left(\mu \mathrm{g} \mathrm{g}^{-1}(\mathrm{dw}) \mathrm{h}^{-1}\right)$ according to

$E=\frac{\left(C_{2}-C_{1}\right) F}{m}$

where $C_{2}$ and $C_{1}$ were the concentrations $\left[\mu \mathrm{L} \mathrm{L}^{-1}\right]$ in the outgoing air and in the inlet air, respectively, and $F$ was the flow rate $\left[\mathrm{L} \mathrm{s}^{-1}\right]$ into the enclosure. The dry weight $[g]$ of the biomass $(m)$ was determined by drying the needles at $75^{\circ} \mathrm{C}$ until consistent weight was achieved. The results are presented as true emission rates without temperature normalization, however the temperatures during measurements are given in the figures to enable the comparison with literature values. 
Table 1. Average, minimum and maximum isoprenoid fluxes $\left(\mathrm{ng} / \mathrm{g}(\mathrm{dw}) \mathrm{h}^{-1}\right)$ measured from four chemotypes of Scots pine and a Norway spruce.

\begin{tabular}{|c|c|c|c|c|c|c|c|c|c|c|c|c|c|c|c|}
\hline & \multicolumn{3}{|c|}{$\begin{array}{c}\text { CHEM1 } \\
N=36\end{array}$} & \multicolumn{3}{|c|}{$\begin{array}{c}\text { CHEM2 } \\
N=20\end{array}$} & \multicolumn{3}{|c|}{$\begin{array}{c}\text { CHEM3 } \\
N=26\end{array}$} & \multicolumn{3}{|c|}{$\begin{array}{c}\text { CHEM4 } \\
N=20\end{array}$} & \multicolumn{3}{|c|}{$\begin{array}{c}\text { SPRUCE } \\
N=10\end{array}$} \\
\hline & Average & Min & Max & Average & Min & Max & Average & Min & Max & Average & Min & Max & Average & Min & Max \\
\hline$(-)-\alpha$-pinene & 1452 & 139 & 6435 & 538 & 71 & 1799 & 44 & 14 & 107 & 47 & 16 & 199 & 536 & 153 & 1202 \\
\hline$(+)-\alpha$-pinene & 1283 & 78 & 7961 & 601 & 30 & 2710 & 254 & 80 & 518 & 226 & 89 & 662 & 59 & 31 & 154 \\
\hline$\beta$-myrcene & 4807 & 332 & 28409 & 136 & 16 & 445 & 80 & 9 & 292 & 69 & 5 & 379 & 211 & 13 & 748 \\
\hline$(+)$-camphene & 29 & 1 & 236 & 8 & 1 & 20 & 12 & 2 & 81 & 7 & 3 & 13 & 327 & 8 & 1012 \\
\hline$(+)$-sabinene & 96 & 9 & 451 & 40 & 6 & 113 & 54 & 0 & 216 & 47 & 7 & 248 & 20 & 3 & 56 \\
\hline$(+)-\Delta$-3-carene & n.d.* & n.d. & n.d. & 700 & 112 & 1767 & 374 & 85 & 1478 & 298 & 36 & 1753 & n.d. & n.d. & n.d. \\
\hline$(+)-\beta$-pinene & 47 & 3 & 284 & n.d. & n.d. & n.d. & n.d. & n.d. & n.d. & n.d. & n.d. & n.d. & 115 & 12 & 299 \\
\hline$(-)-\beta$-pinene & 1763 & 79 & 14470 & 621 & 126 & 1538 & 44 & 4 & 149 & 116 & 37 & 506 & 341 & 15 & 876 \\
\hline (-)-limonene & 544 & 49 & 2540 & 85 & 13 & 265 & 28 & 0 & 99 & 17 & 3 & 63 & 1193 & 91 & 4201 \\
\hline$(+)$-limonene & 180 & 10 & 1061 & 52 & 7 & 186 & 47 & 0 & 141 & 32 & 3 & 118 & 249 & 23 & 881 \\
\hline $\begin{array}{l}(+)-\beta \text { - } \\
\text { phellandrene }\end{array}$ & 3995 & 377 & 16303 & 62 & 10 & 161 & 39 & 0 & 149 & 76 & 10 & 571 & 584 & 23 & 1923 \\
\hline 1,8-Cineole & 576 & 0 & 6978 & n.d. & n.d. & n.d. & n.d. & n.d. & n.d. & n.d. & n.d. & n.d. & 317 & 16 & 1161 \\
\hline$\beta$-caryophyllene & 69 & 0 & 541 & n.d. & n.d. & n.d. & n.d. & n.d. & n.d. & 54 & 8 & 141 & 6 & 0 & 21 \\
\hline$\alpha$-farnesene & 189 & n.d. & 1341 & 54 & 0 & 263 & n.d. & n.d. & n.d. & 415 & 108 & 734 & 11 & n.d. & 70 \\
\hline Total & 15031 & 1089 & 86943 & 3562 & 550 & 9212 & 976 & 231 & 2828 & 1405 & 403 & 5101 & 3968 & 549 & 12181 \\
\hline
\end{tabular}

* n.d.: not detected.

\subsection{Ambient mixing ratio measurements}

An online thermal desorption gas chromatograph-mass spectrometer (TD-GC-MS) instrument was used to measure ambient mixing ratios of monoterpenes from a sampling inlet line installed on the top of the HUMPPA tower $(24 \mathrm{~m})$, approximately $2-3 \mathrm{~m}$ above the canopy. The main sampling line was a $30 \mathrm{~m}, 9.6 \mathrm{~mm}$ i.d. Teflon line through which ambient air was drawn constantly at a flow rate of $7 \mathrm{~L} \mathrm{~min}^{-1}$. The residence time was therefore circa $23 \mathrm{~s}$. Air was drawn from this fast flushed line into a cold VOC enrichment trap held at $10^{\circ} \mathrm{C}$ through a $3.175 \mathrm{~mm}$ Teflon line at a rate of $60 \mathrm{~mL} \mathrm{~min}^{-1}$ using a membrane pump. Ozone was removed from the inlet air using $\mathrm{MnO}_{2}$-coated glass filter (Pollmann et al., 2005). The sampling time was $30 \mathrm{~min}$. More detailed sampling and analysis parameters can be found in Williams et al. (2007), Eerdeekens et al. (2009) and Song et al. (2011).

Blanks were conducted by flowing helium 6.0 (MesserGriesheim, Germany) onto the cold trap under the same conditions as for ambient air. Blanks were taken 7 times during the campaign and they showed no significant levels of the compounds discussed. Calibration was performed every 6-7 samples using the same calibration gas described in the previous section. Laboratory multipoint calibrations were completed prior to the campaign and revealed a good linear dependency of peak area to the respective compound concentration ( $r^{2}$ close to 0.99 for most monoterpenes)

\section{Results and discussion}

During the HUMPPA-COPEC campaign, key BVOC trace gases (isoprenoids) were determined both as direct emissions from the two main boreal forest tree species using branch enclosures, and in ambient air through hourly measurements using TD-GC-MS. By comparing the direct emissions with the photochemically processed ambient air we clarify how the tree species involved influence the chemical composition of the atmosphere over the boreal forest. Furthermore, we were able to determine whether enantiomeric distributions of chiral compounds measured in ambient air correspond to the direct emission of Norway spruce and the four chemotypes of Scots pine.

\subsection{Branch chamber measurement}

\subsubsection{Emission rates from different chemotypes}

Table 1 reports the minimum, maximum and average emission rates of mono- and sesquiterpenes from four chemotypes of Scots pine and Norway spruce. Large differences in emission composition were observed between the individual Scots pine trees, i.e. chemotypes, and between the two evergreen tree species (Fig. 1). For the following analysis the $\Delta-3$-carene content of the Scots pine emission has been used to differentiate the four chemotypes (corresponding with the analysis by Bäck et al., 2012). Strong $\Delta-3$-carene emissions characterized the chemotype 3 , non- $\Delta-3$-carene emissions were observed from chemotype 1 and intermediate level emissions were measured from chemotypes 2 and 4 . Although chemotype 1 emissions contained no $\Delta$-3-carene it nonetheless emitted a suite of monoterpenes and sesquiterpenes comprising $\alpha$ and $\beta$-pinene, $\beta$-myrcene, $\beta$-phellandrene, limonene, 1,8 cineole, $\beta$-caryophyllene and $\alpha$-farnesene. It is important to note that $\beta$-myrcene, a reactive organic trace gas towards ozone and $\mathrm{OH}$ (i.e., Atkinson and Arey, 2003), has not been previously identified due to its coelution with $\beta$ pinene in most of the chromatographic analysis to date. Interestingly, $\beta$-myrcene, was the dominant compound emitted 


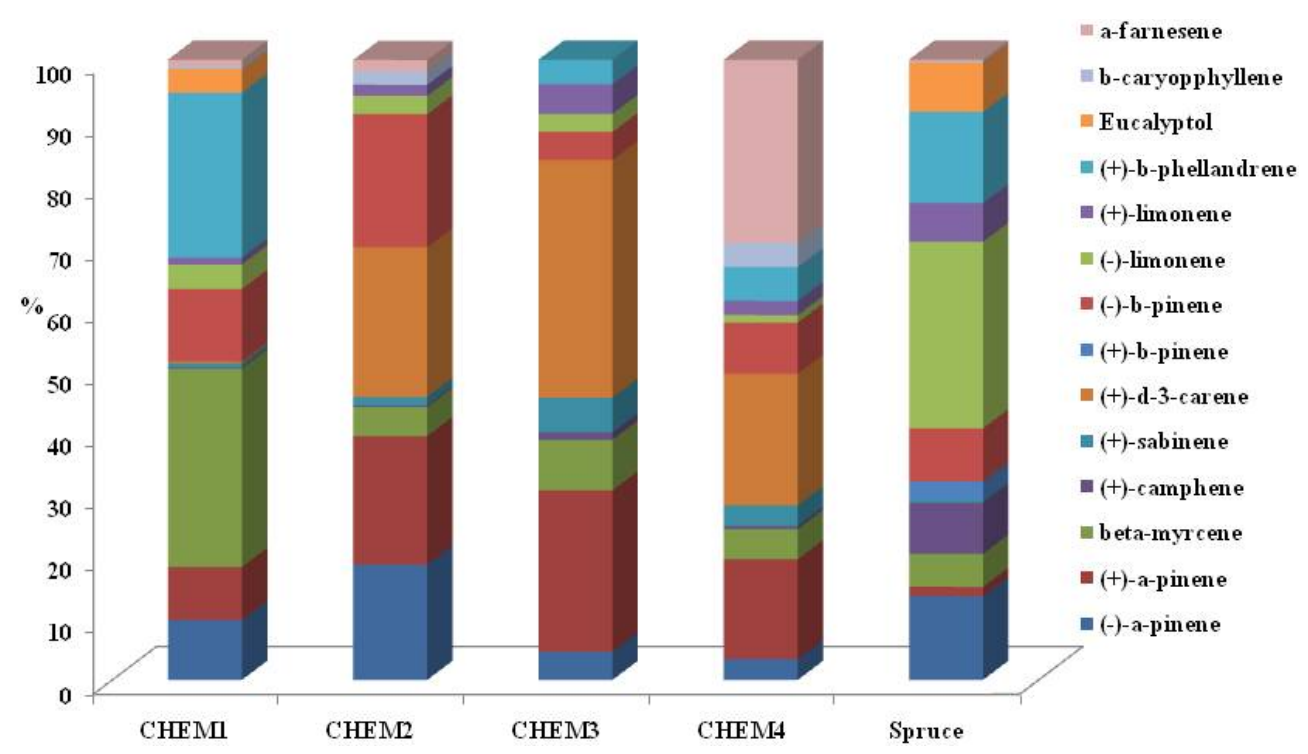

Fig. 1. Chemical composition determined as percentage of total mono- and sesquiterpenes in the emissions of four chemotypes of Scots pine and a Norway spruce.

from chemotype 1 , accounting for more than $32 \%$ of the total mono- and sesquiterpenes. $\beta$-Phellandrene was also abundant constituting around $27 \%$ of total mono- and sesquiterpenes. The dominant sesquiterpene was $\alpha$-farnesene although it accounted for only $1 \%$ of the total mono- and sesquiterpenes. Importantly, chemotype 1 (non- $\Delta$-3-carene chemotype) showed the strongest fluxes of mono- and sesquiterpenes. The total isoprenoid emission rates from this chemotype ranged between 1.1 and $87 \mu \mathrm{g} \mathrm{g}^{-1}(\mathrm{dw}) \mathrm{h}^{-1}$ with the average of $15 \mu \mathrm{g} \mathrm{g}^{-1}(\mathrm{dw}) \mathrm{h}^{-1}$. The emission rates of the dominant compound, i.e. $\beta$-myrcene averaged alone circa $4.8 \mu \mathrm{gg}^{-1}(\mathrm{dw}) \mathrm{h}^{-1}$ and ranged between 0.33 and $28.4 \mu \mathrm{g} \mathrm{g}^{-1}(\mathrm{dw}) \mathrm{h}^{-1}$. The mean emission rate of $\alpha$-farnesene was close to $189 \mathrm{ng} / \mathrm{g}(\mathrm{dw}) \mathrm{h}^{-1}$. It should be noted that the extent to which this chemotype impacts the ambient measured mixing ratios is also a function of its population distribution around the site. Based on the population-level study by Bäck et al (2012), the SMEAR II stand is dominated by the carene chemotype trees, whereas in the surrounding stands the noncarene type is more abundant. This had an impact on the measured atmospheric levels at the site, which were mainly dominated by $\alpha$-pinene, carene being clearly smaller and the second most abundant compound (Bäck et al., 2012).

Among the Scots pine chemotypes, chemotype 2 was the second in terms of the overall emission strength. The emission rates of total mono- and sesquiterpenes fall in the range of 0.5 to $9.2 \mu \mathrm{gg}^{-1}(\mathrm{dw}) \mathrm{h}^{-1}$ and average $3.5 \mu \mathrm{gg}^{-1}(\mathrm{dw}) \mathrm{h}^{-1}$. $\alpha$-Pinene (sum of (+)- and (-)enantiomers), $\Delta$-3-carene and $\beta$-pinene were the major species with $40 \%, 24 \%$ and $21 \%$, respectively. It is interesting to note that high $\beta$-pinene fluxes were only observed in this particular chemotypic tree, with an average of $0.6 \mu g g^{-1}(\mathrm{dw}) \mathrm{h}^{-1}$. Owing to this mixed pinene and carene dominance, this chemotype was classified as intermediate chemotype. Chemotype 4 was ranked third in terms of emission strength. The emission rates of total mono- and sesquiterpenes ranged between 0.4 and $5 \mu \mathrm{gg}^{-1}(\mathrm{dw}) \mathrm{h}^{-1}$ and averaged $1.4 \mu \mathrm{gg}^{-1}(\mathrm{dw}) \mathrm{h}^{-1}$. Interestingly, the emission of $\alpha$-farnesene made up more than $30 \%$ of total mono- and sesquiterpene emission and ranged from 108 to $734 \mathrm{ng} \mathrm{g}^{-1}(\mathrm{dw}) \mathrm{h}^{-1}$ with an average of $415 \mathrm{ng} \mathrm{g}^{-1}(\mathrm{dw}) \mathrm{h}^{-1}$. This is a very high sesquiterpene emission rate, if compared with those published earlier from the same site (Tarvainen et al., 2005; Hakola et al., 2006), where the maxima caryophyllene emissions from an intact shoot were at the range of $150 \mathrm{ng} \mathrm{g}^{-1}(\mathrm{dw}) \mathrm{h}^{-1}$. The emission of $\Delta$-3-carene, $\alpha$-pinene and $\beta$-pinene with $21 \%, 19 \%$ and $8 \%$, respectively, made up almost all the remaining of total monoand sesquiterpene emission. Chemotype 3 or the $\Delta-3$-carene chemotype, was the weakest emitter of mono- and sesquiterpenes. The emission rates of total mono- and sesquiterpenes ranged between 231 to $2828 \mathrm{ng} \mathrm{g}^{-1}(\mathrm{dw}) \mathrm{h}^{-1}$ and averaged $976 \mathrm{ng} \mathrm{g}^{-1}(\mathrm{dw}) \mathrm{h}^{-1}$. The average emission rates of the dominant compound, i.e. $\Delta$-3-carene was $374 \mathrm{ng} \mathrm{g}^{-1}(\mathrm{dw}) \mathrm{h}^{-1}$, which falls within the same range as those reported for this compound and from the same class of chemotype monitored during the same period (July) by Hakola et al., 2006.

The emission rates of total mono- and sesquiterpenes from Norway spruce ranged from 0.5 and $12.1 \mu \mathrm{g} \mathrm{g}^{-1}(\mathrm{dw}) \mathrm{h}^{-1}$ and averaged circa $4 \mu \mathrm{gg}^{-1}(\mathrm{dw}) \mathrm{h}^{-1}$. Limonene $(36 \%), \alpha$ pinene $(15 \%), \beta$-phellandrene (15\%), $\beta$-pinene $(11 \%)$ and 1,8 -cineole $(8 \%)$ were the dominant emitted monoterpenes. $\Delta$-3-Carene was also present in the emission of spruce. 
To evaluate to what extent mono- and sesquiterpenes emitted from Scots pine chemotype 1 present similar emission pattern, correlations were established between $\beta$-myrcene and $\beta$-phellandrene $\left(r^{2}=0.9606\right), \beta$-myrcene and $\alpha$-pinene $\left(r^{2}=0.8966\right), \alpha$-farnesene and $\beta$-myrcene $\left(r^{2}=0.8175\right)$ and $\alpha$-farnesene and $\alpha$-pinene $\left(r^{2}=0.8597\right)$. Rather high correlations were obtained suggesting that a similar common emission mechanism was responsible. High correlations were also observed in chemotype 4 when plotting $\Delta$-3-carene against both $(+)$ - $\alpha$-pinene $\left(r^{2}=0.9377\right)$ and $\beta$-myrcene $\left(r^{2}=0.9943\right)$ and $(+)-\alpha$-pinene against $\beta$-myrcene $\left(r^{2}=0.9625\right)$. However, chemotype 3 and chemotype 2 revealed bad correlations between the dominant compounds, e.g., in chemotype 3, $(+)$ - $\alpha$-pinene vs. $\Delta$-3-carene $\left(r^{2}=0.6464\right), \Delta$-3-carene vs. $\beta$-myrcene $\left(r^{2}=0.5297\right)$, chemotype $2, \Delta$-3-carene vs. $\alpha$ pinene $\left(r^{2}=0.2206\right)$.

Not only the chemotypic diversity in forests impacts the chemical composition of the atmosphere. Since emissions from the non- $\Delta-3$-carene chemotype were over one order of magnitude higher than the $\Delta-3$-carene chemotype, the abundance and distribution of this Scots pine chemotypic individual is of great importance for the atmospheric chemistry at the site. As Bäck et al. (2012) have reported, a high proportion of this chemotype in the surrounding forest affects atmospheric chemistry and especially the $\mathrm{OH}$ concentrations and thus should be taken into account in chemistry modelling. The strong chemotype effect manifested in high emission rates could possibly reduce the reported large difference between measured and modelled $\mathrm{OH}$ reactivity at the site (Mogensen et al., 2011) and further affect the assessment of aerosol formation.

As will be discussed in Sect. 3.2 related to the ambient atmospheric measurements, the published above-canopy concentrations at the site have been dominated by $\Delta$-3-carene and $\alpha$-pinene, with some sabinene, limonene and 1,8-cineole (Hakola et al., 2003, 2009), while $\beta$-myrcene was present only at low concentrations. This is in contrast with our finding namely strong emissions of myrcene from chemotype 1 . This apparent discrepancy can be understood as $\Delta$-3-carene and $\beta$-myrcene have distinctly different lifetimes in the atmosphere for reactions with $\mathrm{OH}(1.6 \mathrm{~h}$ for $\Delta$-3-carene and $39 \mathrm{~min}$ for $\beta$-myrcene) and $\mathrm{O}_{3}$ (11 h for $\Delta$-3-carene and $50 \mathrm{~min}$ for $\beta$-myrcene) (i.e. Atlkinson and Arey, 2003). The high fluxes of $\beta$-myrcene measured on the branch scale from chemotype 1 are much more rapidly oxidised in the atmosphere due to the reaction with $\mathrm{OH}$ radicals and ozone, and therefore measurements of myrcene from above canopy are rendered difficult due to dwindling concentrations. Nonetheless large discrepancies between the measured branch scale emission patterns and above-canopy concentrations possibly indicate that measurements of emissions on the individual tree scale are insufficient to characterize the interactions at stand, population or footprint scale.

The large variation in tree-specific emission patterns influences the overall stand-level emission fluxes and thus

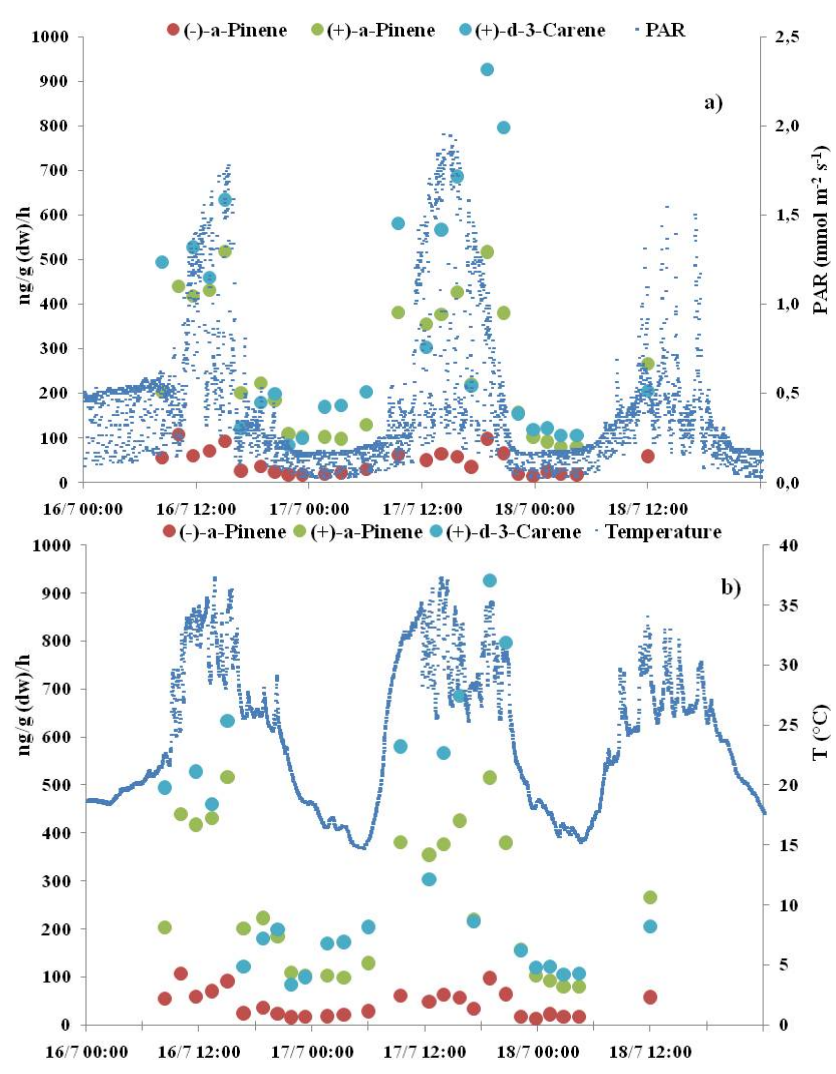

Fig. 2. Diel cycles of the fluxes of the major monoterpenes in the emission of Chemotype 3 plotted with PAR (a) and temperature (b) inside the enclosure cuvette.

the aerosol formation processes are expected to be also affected. Since the emission measurements commonly are made from one or a few trees, the representativeness of these to the stand-level air chemistry is highly questionable, especially as the emission magnitude also seems to largely vary with chemotype. More comprehensive measurements and population-level studies are needed to upscale from leaf level to stand or regional level emissions.

\subsubsection{Diel cycles in direct plant emission}

Diel cycles of the dominant monoterpenes in chemotypes 3 and 1 with both PAR (photosynthetically active radiation) and temperature are displayed in Figs. 2a and $b$ and $3 a$ and $\mathrm{b}$, respectively. Although not clearly observed, the trends of monoterpene emission rates followed to some extent the variations of light and temperature. It seems from these profiles that temperature is the dominant driver for the emission of monoterpenes as it more closely corresponds to the observed variations. In Scots pine the majority of synthesized monoterpenes are stored in resin ducts within the needles (Ghirardo et al., 2010, and references therein), although more than half of the emissions can originate from de novo synthesis at a given time. Traditionally it has been suggested that emissions 


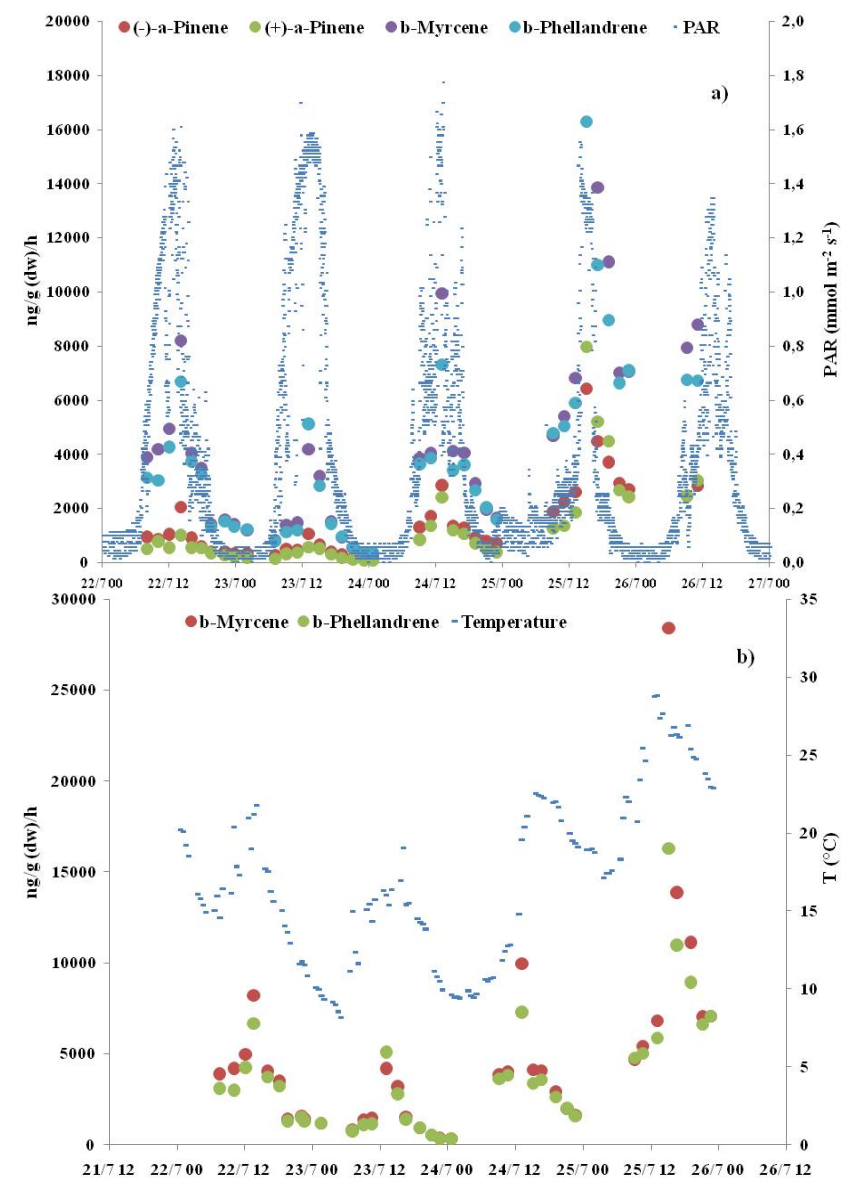

Fig. 3. Diel cycles of the fluxes of the major monoterpenes in the emission of chemotype 1 plotted with PAR (a) and temperature (b) inside the enclosure cuvette.

are physically controlled by temperature through the process of evaporation or diffusion. As the monoterpene fluxes from the different chemotypes were not examined in parallel it is not possible to compare the temporal trends of isoprenoid emission from each chemotype throughout the campaign. However, if we consider chemotype 1 for which the emission was monitored through periods of low and high temperatures, we can see clearly how strongly the increase of temperature affected the emission of isoprenoids. The total isoprenoid emissions easily reached some $87 \mu \mathrm{g} \mathrm{g}^{-1}$ (needle dry weight) $h^{-1}$. This huge amount was likely due to the unusually high boreal summer temperatures. The increase in temperature induced not only increases in monoterpene flux rates but also a change in the chemical composition. For example the flux of $\alpha$-farnesene, which was close to the detection limit at low temperature, increased substantially as temperature rose. The thermoprotection hypothesis has so far been studied mainly in laboratory conditions with Mediterranean species such as Quercus ilex, and related to either isoprene or monoterpene emissions, (e.g. Singsaas et al., 1997; Loreto et al., 1998; Copolovici et al., 2005), but our data con- firms the previously noted strong temperature dependency of sesquiterpene emissions from Scots pine in field conditions (e.g. Staudt and Lhoutellier, 2011; Jardine et al., 2011). It has been noted previously that the temperature dependence factor for sesquiterpenes (beta in the Guenther emission algorithm) is higher than that of monoterpenes for many pine trees (Helmig et al., 2007). Thus as temperatures increase the sesquiterpene emissions would increase at a faster rate. The change in composition noted at high temperature may well reflect this response. Therefore not only flux rates but also composition changes in boreal forest emissions at higher temperatures must be considered when assessing future boreal climate warming impacts, in particular when assessing feedbacks due to the formation of secondary organic aerosol and consequent influences on the intensity of PAR.

\subsubsection{Chiral distribution in the plant emission}

Many monoterpenes emitted in large amounts by coniferous trees are chiral (exist in two mirror image forms) and are most likely produced by specific enzymes within the plant (Martin et al., 2002, and references therein). Investigations of the enantiomeric distribution of monoterpenes in different tissues of Scots pine and Norway spruce, based on solvent extraction methods, showed clear chemical composition differences between the tissues analysed. For example, the needles of Norway spruce were relatively rich in (-)-camphene compared with other tissues (such as xylem, phloem and oleoresin of branch), while (+)- and (-)- $\alpha$-pinene and (-)- $\beta$ pinene were found to be relatively rich in tissues other than needles (Persson et al., 1993). The enantiomeric composition was also found to change from more (-)-enantiomer $(\alpha$-pinene and limonene) in the younger parts to more $(+)$ enantiomer in the older parts (Persson et al., 1993). However, these studies do not reflect the natural emission of plants to the atmosphere because of the damage to the plant tissues caused by sampling which leads to a drastic change in both chemical composition and enantiomeric distribution of emitted terpenes. Indeed, large changes in branch emissions of terpene enantiomers have been reported when mechanical stress is applied (Yassaa and Williams, 2007).

The present study represents the first intensive investigation on the chirality of monoterpenes present in both direct plant emission and ambient air in the boreal forest. Whereas direct emissions from chemotype 1 and chemotype 2 showed to be a racemate for $\alpha$-pinene, chemotype 3 and chemotype 4 revealed high preference for $(+)-\alpha$-pinene, being almost 6 and 5 times enriched in chemotype 3 and chemotype 4 , respectively. $\beta$-pinene, even though weakly emitted in most of the cases, was almost exclusively present as (-)$\beta$-pinene in the emission of all four chemotypes. In contrast, Norway spruce exhibited a strong preference for the (-)-enantiomeric form in both $\alpha$ - and $\beta$-pinene (on average (-)- $\alpha$-pinene was 9 times higher than $(+)-\alpha$-pinene and $(-)-\beta$-pinene was 3 times higher (+)- $\beta$-pinene). These chiral 


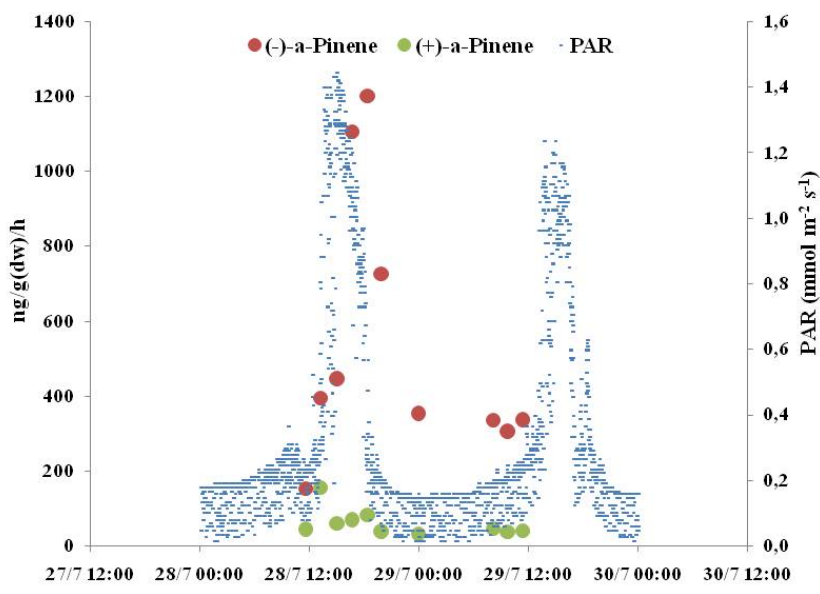

Fig. 4. Diel cycle of (+)- and (-)- $\alpha$-pinene in the emission of Norway spruce plotted with PAR inside the enclosure cuvette. Figure 5. Mixing ratios of measured biogenic VOC over the campaign. The marker represents the middle of the sampling time. The gaps were caused by calibration and blanks measurements, power failures or mixing ratios below detection limits.

characterizations underline that not only the chemical composition is distinct between the four chemotypic trees but also the stereochemistry of emitted monoterpenes. This also suggests that the chemical composition and enantiomeric emission preference are genetically controlled.

While the diel cycles of (+)- and (-)- $\alpha$-pinene emitted from the four individual chemotypic trees of Scots pine did not reveal any clear profile with light and temperature, those determined in the emission of Norway spruce are particularly interesting (Fig. 4). Whilst (+)- $\alpha$-pinene fluxes remained stable over time, $(-)-\alpha$-pinene showed a distinct Gaussian shaped profile and peaked between 16:00 and 18:00 local time. The maximum (-)- $\alpha$-pinene emission rates appear to be following the PAR level with a small delay. This suggests that the (-)- $\alpha$-pinene is synthesized in a light dependent process, whereas the steady levels of (+)- $\alpha$-pinene imply that these emissions originate from permanent storage in resin ducts, and are less influenced by incident light levels.

\subsection{Measurement of ambient air}

\subsubsection{Temporal variation of VOC}

Figure 5 presents the overview of the main Biogenic VOC measured by TD-GC-MS from 13 July to 10 August 2010. The data points represent the middle of the sampling period. The short data gaps were caused by blanks and calibration measurements and the larger ones were due to power failures at the station caused by thunderstorm-associated lightning.

In Fig. $5,( \pm)$ - $\alpha$-pinene, $\Delta$-3-carene, $( \pm)$ - $\beta$-pinene and isoprene are shown. These were found to be the most abundant biogenic compounds measured in ambient air during the whole period of the HUMPPA-COPEC summer campaign.
Small amounts of other monoterpenes such as $\beta$-myrcene and limonene were also observed. Generally, the predominant compounds were $\Delta$-3-carene and $\alpha$-pinene with approximate relative contributions of $20-45 \%$ and $35-60 \%$ of the total observed monoterpenes, respectively. $\Delta$-3-carene ranged from $5 \mathrm{pptv}$ to $1.4 \mathrm{ppbv},(-)-\alpha$-pinene from $7 \mathrm{pptv}$ to $0.5 \mathrm{ppbv}$, and (+)- $\alpha$-pinene from $9 \mathrm{pptv}$ to $1.5 \mathrm{ppbv}$. Both enantiomers of $\alpha$-pinene and $\beta$-pinene were detected during the measurement period. Interestingly the mixing ratios of $(+)-\alpha$-pinene were always higher than the $(-)$-enantiomer whereas the (-)-pinene was always overwhelmingly higher than the (+)-pinene enantiomer. The median values were for $\Delta$-3-carene $35 \mathrm{pptv},(-)-\alpha$-pinene $27 \mathrm{pptv},(+)-\alpha$-pinene $39 \mathrm{pptv},(-)-\beta$-pinene $20 \mathrm{pptv}$ and isoprene $56 \mathrm{pptv}$. Isoprene mixing ratios, which were higher at the beginning and the end of the campaign, ranged from a few pptv to more than 600 pptv.

It is worth emphasizing that the spectrum of compounds present in ambient air is a function of the emission rate from the surrounding forest ecosystem, the reactivity of the chemical, and the distribution of the above described Scots pine chemotypes relative to the measurement point. For example, although myrcene is strongly emitted by chemotype 1 its high reactivity with respect to $\mathrm{OH}$ and $\mathrm{O}_{3}$ causes that it is not detected in ambient air. The photochemical products of myrcene, however, likely contribute to the high missing reactivity determined at the site (Nölscher et al., 2012).

\subsubsection{Diel cycles of VOC in ambient air}

The diel cycles of selected biogenic VOC measured during the HUMPPA-COPEC campaign are shown in Fig. 6. The blue dots illustrate the median value of the mixing ratio, the open triangle represents the mean value, the upper and lower bars represent the maximum and minimum value and the box top and bottom show the percentile of 75 th and 25 th respectively.

All the monoterpenes follow a similar trend: a slow decrease of the mixing ratios starts in the morning around 08:00 towards the daytime with the minimum around 12:00, and after 15:00-16:00 the mixing ratio begins to increase again, reaching a maximum after 21:00, and remaining high and stable throughout the night until the following morning. Local noon was approximately 12:30. Despite coniferous trees emitting monoterpenes as a function of temperature and light (Guenther et al., 1997; Tarvainen et al., 2005) the maximum ambient concentrations were observed at night. This apparent paradox is due to increases in the boundary layer height and turbulence as well as in the primary atmospheric oxidant $\mathrm{OH}$ by day. Although the emission fluxes from the boreal forest are certainly higher by day (high light and temperature), the boundary layer into which they are mixing is some 15 times higher by day (ca. $1500 \mathrm{~m}$ ) than by night $(\mathrm{ca} .100 \mathrm{~m})$. This and the attenuating effect of the $\mathrm{OH}$ reaction on concentration by day lead to the observed diel cycle. 

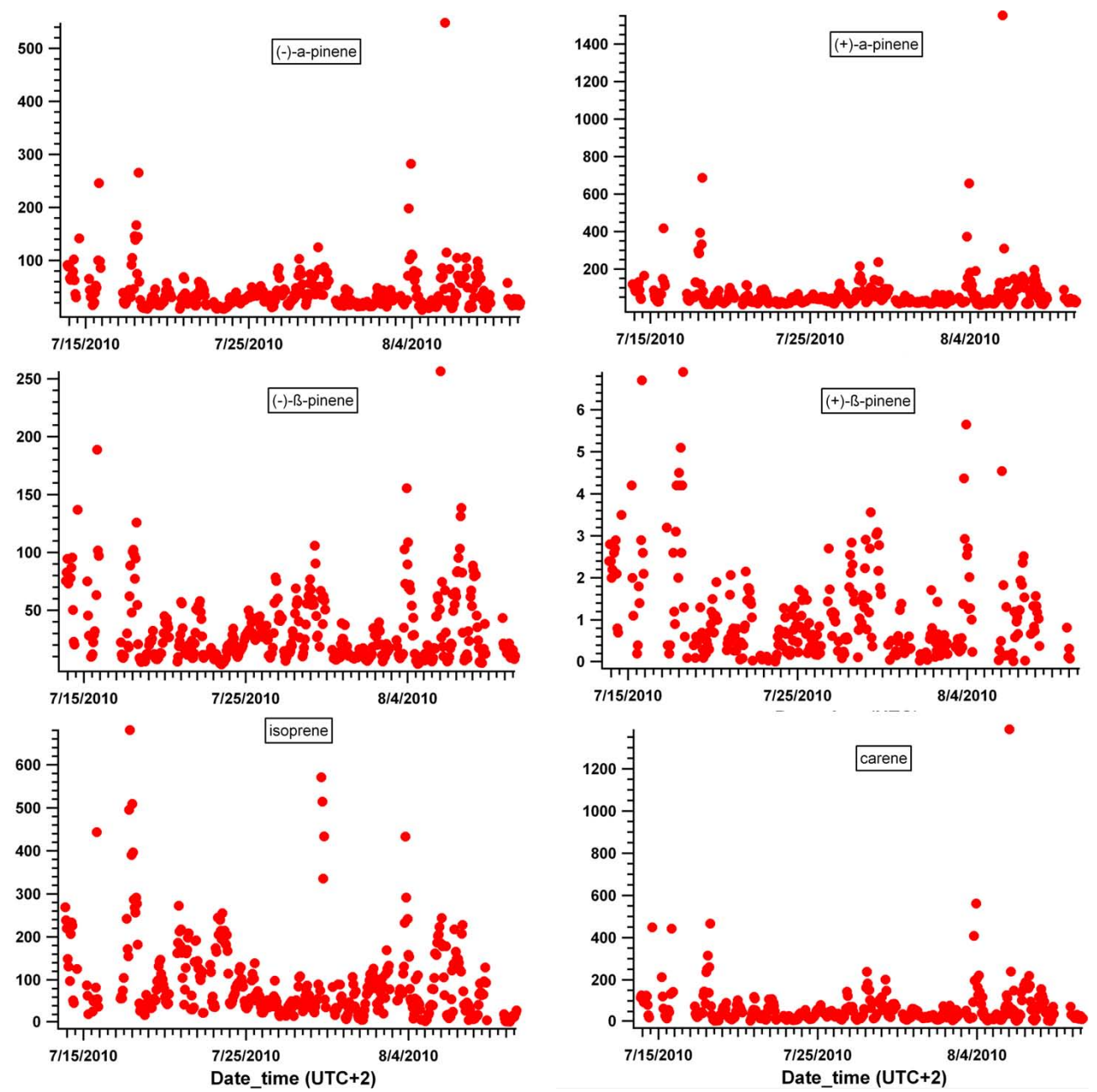

Fig. 5. Mixing ratios (pptv) of measured biogenic VOC over the campaign. The marker represents the middle of the sampling time. The gaps were caused by calibration and blanks measurements, power failures or mixing ratios below detection limits.

Close inspection of the median isoprene diel profiles shows the presence of three peaks. In addition to the peak centred around 12:00 there are two peaks (07:00 and 19:00) for the temperature- and light-dependant compound isoprene. Thereafter it decreased until midnight and remained stable the whole night. Previous studies have shown that spruce and aspen are strong isoprene emitters (Janson and De Serves 2001; Hakola et al., 2000) and that light is the primary driver for isoprene emission (Guenther et al., 1995). Generally, the temperature reached its maximum around 15:00 and the maximum radiation levels observed were from 11:00 to 14:00. Double peaks for isoprene have been seen at other sites and usually the second peak occurs late in the afternoon (e.g. Dreyfus et al., 2002). In some cases such peaks have been attributed to transport from upwind isoprene emitting regions. Another possible explanation is that isoprene is produced in a post-illumination pulse as small reservoirs of the compound or precursors are vented or processed (e.g. Monson et al., 1991; Li et al., 2011). However, this latter process would not explain the early morning peak. In this study we suggest that the multiple peaks are caused by variation in the boundary layer height and the unusually long daylight time in the boreal summer. Illumination of the tree by the early morning sun (sunrise 04:00) may instigate isoprene emission before the rise of the boundary layer. Likewise under these conditions the sunlight may persist after the boundary layer has formed in the evening. In both cases emissions would occur into a shallow boundary layer and give rise to a peak in concentration. The larger size of the late afternoon peak would then be explained by the larger average temperature at this time compared to the early morning. It is noted that the two enantiomers of $\alpha$-pinene appear to show very similar diel cycles, although their ratio changes distinctly as is discussed in the following Sect. 3.2.3. 

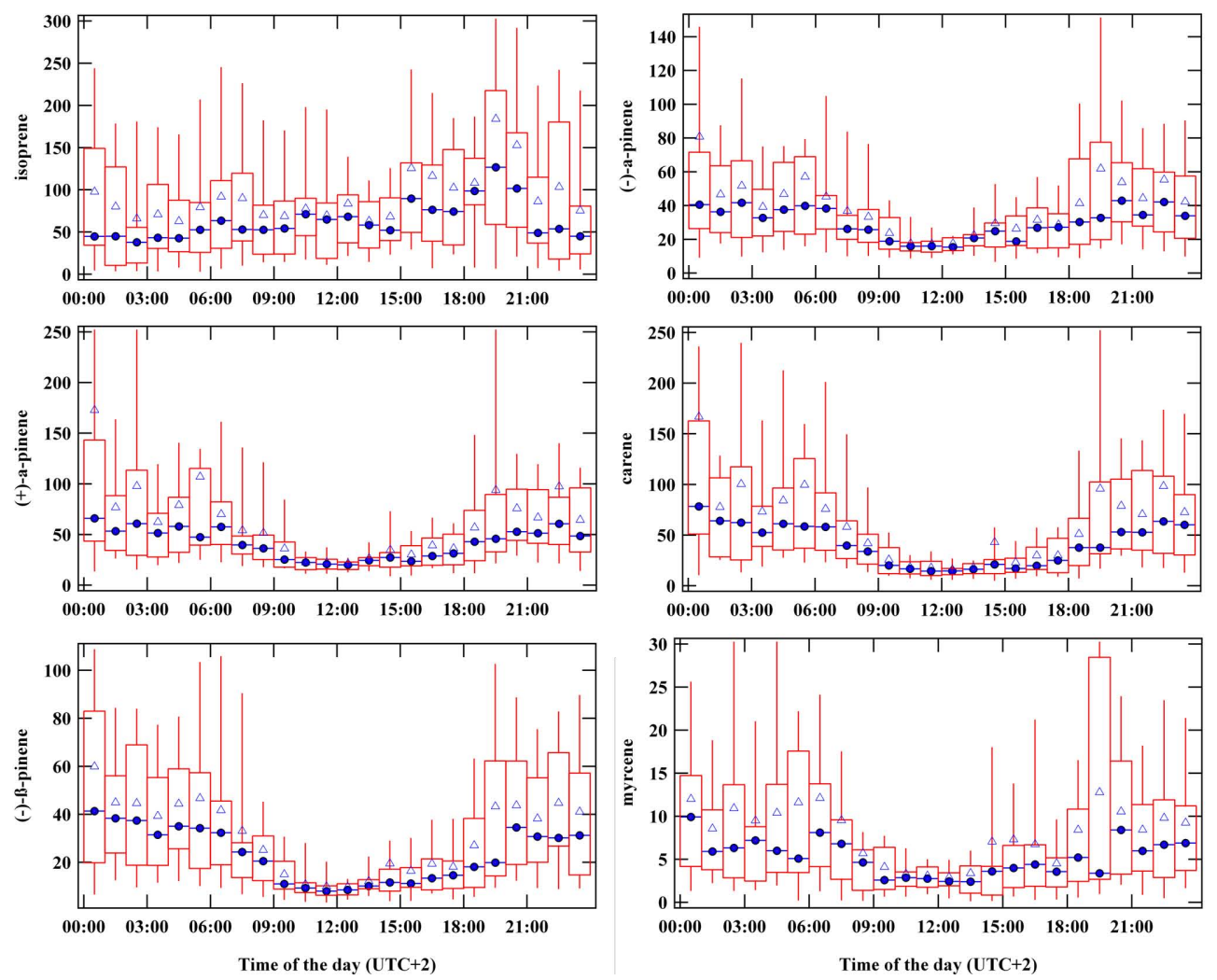

Fig. 6. Diel cycle of BVOC during the campaign. The dots represent the median value of every hour, the open traingle represents the mean value, the box top and bottom represent the percentile of 75 th and 25 th.

\subsubsection{Chiral distribution in ambient air}

The enantiomeric signature of monoterpenes in the atmosphere was determined for the first time in a Boreal forest during the Biosphere Aerosol Cloud Climate Interactions Quantification of Aerosol Nucleation in the European Boundary Layer (BACCI4-QUEST 2005) intensive field campaign conducted in Hyytiälä, Finland in April-May, 2005 (Williams et al, 2007; Eerdekens et al., 2009). By contrasting the results of this campaign with a jet aircraft measurements of enantiomeric monoterpenes over a pristine rainforest conducted under GABRIEL campaign (Guyanas Atmosphere-Biosphere exchange and Radicals Intensive Experiment with the Learjet, 2005), it has been established that distinct regional chiral signatures exist, and that ambient mixing ratios of the $\alpha$-pinene enantiomers always favours $(+)-\alpha$-pinene over the boreal forest and (-)- $\alpha$-pinene over Amazonia (Williams et al., 2007). The present results from the HUMPPA-COPEC campaign are in agreement with this previous study, although it should be noted that the measurements were made at the same site albeit at a different time of the year. Previous measurements in temperate forests show strong winter/summer enantiomeric variation (Song et al., 2011). The summertime average ratio of $(-) /(+)-\alpha-$ pinene found during HUMPPA-COPEC was 0.7 and the (+)enantiomer exceeded (-) in all samples.

Comparing the aforementioned measurements from branch cuvette enclosures of the four different chemotypic species, the dominance of the emissions from the chemotype 3 is reflected not only by the abundance of $\Delta-3$-carene in the atmosphere but also by the enantiomeric preference for (+)- $\alpha$-pinene. This suggests that chemotype 3 with high content of $\Delta$-3-carene and enantiomeric preference for $(+)$ $\alpha$-pinene remains the most dominant Scots pine chemotype in the Hyytialä forest environs and the emissions from other chemotypes, despite giving rise to different chemical compositions, and chiral distributions are overwhelmed by the prevalence of $\Delta$-3-carene chemotype. In other words, the population dominance of chemotype 3 more than compensates for its weaker emission relative to chemotype 1 . This is in agreement with Bäck et al. (2012) who concluded that the SMEAR II site is dominated by the carene chemotype.

Interestingly, from the HUMPPA-COPEC dataset we can see that unlike $\alpha$-pinene, the ambient concentrations of $\beta$ pinene showed a reverse enantiomeric distribution. In this case the (-)- $\beta$-pinene enantiomer dominates throughout the dataset. The (+)- $\beta$-pinene enantiomer was often below detection limit suggesting that a more stereoselective mechanism is governing its production. This is supported by the results 


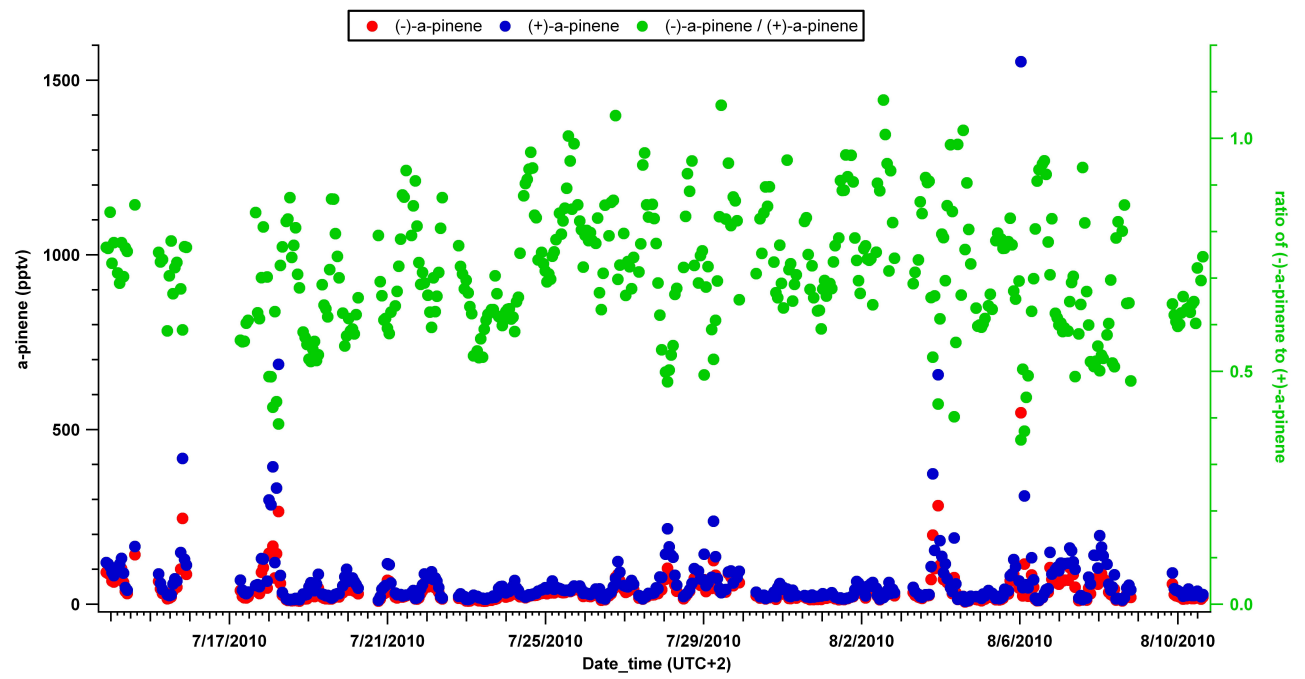

Fig. 7. Enantiomeric ratio of $\alpha$-pinene and mixing ratios of (-)- $\alpha$-pinene and (+)- $\alpha$-pinene over the HUMPPA-COPEC campaign.

obtained in all the branch chamber measurements where the emissions from the four chemotypes of Scots pine and Norway spruce were largely dominated by (-)- $\beta$-pinene.

Previous experiments highlighted that the damage to the needles of the Scots pine induced higher ratios of the (+)enantiomer of $\alpha$-pinene (Yassaa and Williams, 2007). This finding has proved useful in identifying the events of high emissions from a nearby sawmill (Eerdekens et al., 2009). In our data, this influence manifested itself as unusually high concentrations of monoterpenes and as a clear enrichment of $(+)-\alpha$-pinene over its ( -$)-\alpha$-pinene enantiomer. These events were also associated with a southeasterly wind direction corresponding to the bearing of the mill from the site. Figure 7 shows the mixing ratios of both $\alpha$-pinene enantiomers and their ratio for the 2010 HUMPPA-COPEC campaign. On several occasions the peak concentrations are associated with enantiomeric ratio enrichments. These events (e.g. in the period 3 August 21:00-4 August 00:00) did coincide with short episodes of southeasterly winds suggesting that on this campaign sporadic influences of the sawmill on the dataset have been detected.

Figure 8 shows the diel cyles of (-)-enantiomer enrichment, which is calculated as enantiomeric excess following the formula: (-)-enantiomer $\%=(-)$-enantiomer $/((-)$ enantiomer $+(+)$-enantiomer $) \cdot 100$

As shown in Fig. 8, (+)- $\alpha$-pinene was dominant in the enantiomeric composition with the enrichment over $50 \%$ all the time, however, $(-)-\alpha$-pinene did show a distinct increase through the day peaking around 11:00 to 14:00. As previously mentioned it has been established that monoterpenes are emitted from resin ducts, which means the temperature controls their volatilization from storage pools inside the leaf (Ciccioli et al., 1997; Guenther et al., 1993). However, several studies have reported that both light and temperature control terpenoid emissions other than isoprene
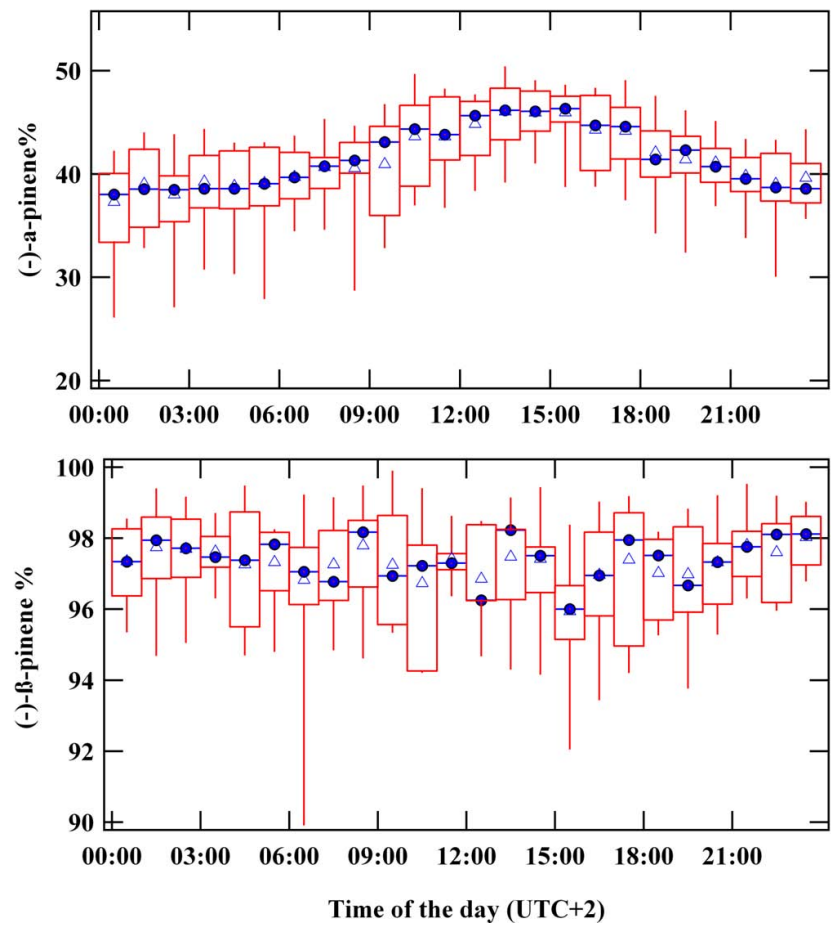

Fig. 8. Diel cycle of (-)-enantiomers enrichment ((-)enantiomer $\%=(-)$-enantiomer/( $(-)$-enantiomer $+(+)$ enantiomer).100) during the campaign. The dots represent the median value of every hour, the open traingle represents the mean value, the box top and bottom represent the percentile of 75 th and 25 th.

from Scots pines (Shao et al., 2001; Komenda et al., 2003; Bäck et al., 2005; Ghirardo et al., 2010). As can be seen from Fig. 9 which shows the (-)- $\alpha$-pinene enrichments colour coded with temperature, light and ozone concentration, the 


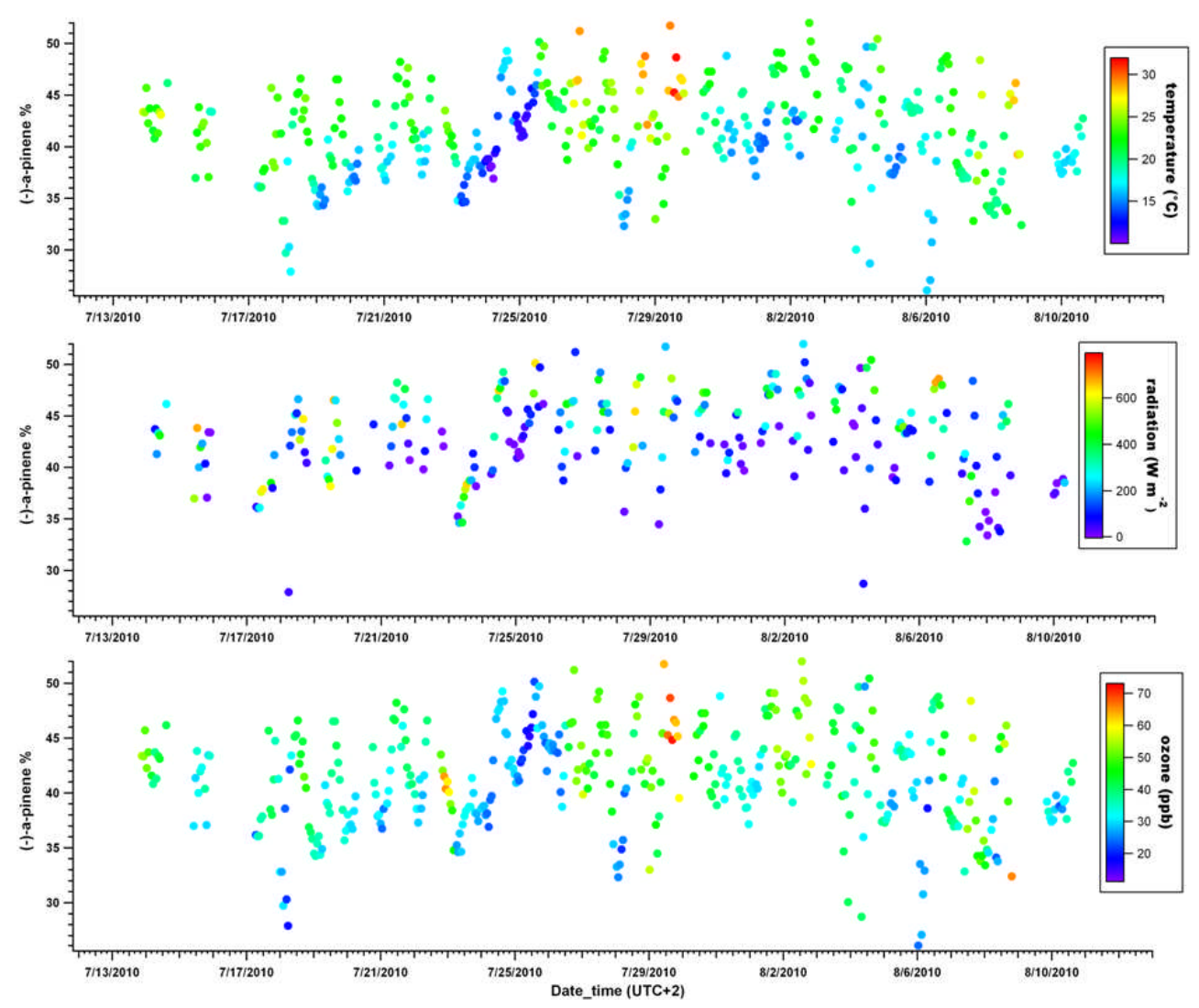

Fig. 9. Air (-)- $\alpha$-pinene enrichment color coded with temperature, radiation, and ozone concentration during the HUMPPA-COPEC campaign.

higher temperatures were always correlated with the higher concentrations of $(-)-\alpha$-pinene, while there was a delay of one or two hours for the (-)-enantiomers enrichment peaks every day compared with the maximum radiation. This reflects two things: first, the temperature regulates the volatility and diffusion of already existing monoterpenes in the leaf. Secondly, especially the biosynthesis of $(-)-\alpha$-pinene is dependent of light levels, which either activate the synthase enzymes, or provide the necessary energy for biosynthesis, or most likely, both. The time delay between light maximum and emission peak reflects the time constant of the biosynthesis process. This is the first time that biosynthesis of monoterpene molecules has been directly connected to light levels in field conditions.

With regards to ozone, the correlation is not very high. Recently, laboratory studies have shown that ozone reacting with enantiomers on a surface can cause an abiological enrichment (Stokes et al., 2009). However, these field measurements appear to not support that this mechanism is significant for the conditions encountered during this field campaign.

As mentioned in the results from the branch enclosure experiments (Sect. 3.1.2), the emissions from Norway spruce, the second most common tree species after Scots pine, manifested a reverse enantiomeric preference for $\alpha$-pinene where (-)-enantiomer was 9 times more enriched than (+)enantiomer. Furthermore, it showed a diel cycle where (-)$\alpha$-pinene peaked around 16:00 and 18:00 and (+)- $\alpha$-pinene remained constant over the time. It could be that the diel cycle in the ambient air enrichment of $(-)-\alpha$-pinene shown in Fig. 8 is a combination of the temperature and radiation effects and a contribution from the emission of spruce even though the peaks in the direct spruce emission and ambient air did not coincide at the same time. The latter assumption is supported by the fact that the measured isoprene in ambient air during the campaign comes very likely from Norway spruce as Scots pine is not an isoprene emitter and (-)- $\alpha$ pinene did not show any clear diel cycles in any of the four studied chemotypes of Scots pine. In contrast, another chiral pinene, $\beta$-pinene, showed a very strong ambient air (-)enantiomer preference as observed in the emissions of the four chemotypes of Scots pine and Norway spruce. The relative amount of (-)-enantiomer was over $90 \%$ of the total $\beta$-pinene. 


\section{Conclusions}

Organic trace gases in the summertime Boreal forest environment were characterized during the HUMPPA-COPEC 2010 campaign at the Hyytiälä SMEAR II station from 12 July until 12 August as direct plant emissions using branch enclosures and SPME-GC-MSD, and in ambient air by means of online TD-GC-MS.

The measurement of direct plant emission confirmed the existence of specific chemotypes of Scots pines: a $\Delta$-3-carene chemotype; a non- $\Delta-3$-carene chemotype and intermediate chemotypes. The non- $\Delta-3$-carene chemotype showed the strongest emission of terpenes (15 times higher than the $\Delta-3$-carene chemotype). A novel finding was that a high emission of $\beta$-myrcene and $\beta$-phellandrene was detected from Scots pine branches, not commonly measured at the SMEAR II site before. Chemotypic diversity was found to affect not only the chemical composition of emitted terpenes but also their stereoisomery. While the $\Delta-3-$ carene chemotype manifested strong preference for $(+)-\alpha-$ pinene, the non- $\Delta-3$-carene chemotype was a racemate for $\alpha$-pinene. All chemotypes emitted almost exclusively (-)$\beta$-pinene. Norway spruce showed strong preference for (-)enantiomers for both $\alpha$-pinene and $\beta$-pinene.

The unusual high boreal summer temperatures were accompanied by relatively high fluxes of terpenes and greater diversity in the emitted chemical compositions. Since insects and plants discriminate and respond to chiral compounds (e.g. Tumlinson, 1988), changing the emission composition may influence the effectiveness of insect/plant or plant/plant communication in a future warmer climate conditions.

The total ambient monoterpenes (including $\alpha$-pinene, $\Delta$ 3 -carene, $\beta$-pinene and $\beta$-myrcene) measured above the canopy during the campaign varied in mixing ratio from a few pptv to over one ppbv. The main biogenic BVOC measured above the canopy were $\alpha$-pinene and $\Delta$-3-carene and these two compounds together contributed more than $50 \%$ of the total monoterpenes. Isoprene mixing ratios were also detected during the summer campaign. The measurement of the chirality in the atmosphere showed predominance of (+)$\alpha$-pinene over the entire campaign which is in keep with the previous study at the same site (Williams et al., 2007). This also suggests that $\Delta$-3-carene chemotypes of Scots pine, which emit preferentially (+)- $\alpha$-pinene, are dominant and more widespread in the vicinity of Hyytiälä. Interestingly, (-)-enantiomer of $\beta$-pinene which largely prevails in the emissions of the studied chemotypes of Scots pine and Norway spruce, was also dominant in the ambient air. The ambient diel cycle of the enantiomeric enrichment of (-)$\alpha$-pinene, can be explained by the contribution of Norway spruce which also shows a clear diel cycle with the emission of (-)- $\alpha$-pinene. The timing of the enantiomer emissions reflects the biological processes behind the emissions; temperature regulates volatilization, and incident light the biosynthesis.
Acknowledgements. The entire HUMPPA-COPEC team is grateful for the support of the Hyytiälä site engineers and staff.

The service charges for this open access publication have been covered by the Max Planck Society.

Edited by: A. Goldstein

\section{References}

Atkinson, R., and Arey, J.: Gas-phase tropospheric chemistry of biogenic volatile organiccompounds: a review, Atmos. Environ., 37, S197-S219, 2003.

Bäck, J., Hari, P., Hakola, H., Juurola, E., and Kulmala, M.: Dynamics of monoterpene emissions in Pinus sylvestris during early spring, Boreal Environ. Res., 10, 409-424, 2005.

Bäck, J., Aalto, J., Henriksson, M., Hakola, H., He, Q., and Boy, M.: Chemodiversity of a Scots pine stand and implications for terpene air concentrations, Biogeosciences, 9, 689-702, doi:10.5194/bg-9-689-2012, 2012.

Ciccioli, P., Fabozzi, C., Brancaleoni, E., Cecinato, A., Frattoni, M., Loreto, F., Kesselmeier, J., Schafer, L., Bode, K., Torres, L., and Fugit, J. L.: Use of the isoprene algorithm for predicting the monoterpene emission from the Mediterranean holm oak Quercus ilex L.: Performance and limits of this approach, J. Geophys. Res., 102, 23319-23328, 1997.

Claeys, M., Graham, B., Vas, G., Wang, W., Vermeylen, R., Pashynska, V., Cafmeyer, J., Guyon, P., Andreae, M. O., Artaxo, P., and Maenhaut, W.: Formations of secondary organic aerosols through photooxidation of isoprene, Science, 303, 1173-1176, 2004.

Copolovici, L., Filella, I., Llusia, J., Niinemets, U., and Penuelas, J.: The capacity for thermal protection of photosynthetic electron Transport varies for different monoterpenes in Quercus ilex, Plant Physiol., 139, 485-496, 2005.

Dreyfus, G. B., Schade, G. W., and Goldstein, A. H.: Observational constraints on the contribution of isoprene oxidation to ozone production on the western slope of the Sierra Nevada, California, J. Geophys. Res., 107, 4365, doi:10.1029/2001JD001490, 2002.

Eerdekens, G., Yassaa, N., Sinha, V., Aalto, P. P., Aufmhoff, H., Arnold, F., Fiedler, V., Kulmala, M., and Williams, J.: VOC measurements within a boreal forest during spring 2005: on the occurrence of elevated monoterpene concentrations during night time intense particle concentration events, Atmos. Chem. Phys., 9, 8331-8350, doi:10.5194/acp-9-8331-2009, 2009.

Ghirardo, A., Koch, K., Taipale, R., Zimmer, I., JÖRG-PETER Schnitizler, J. P., and Rinne, J.: Determination of de novo and pool emissions of terpenes from four common boreal/alpine trees by ${ }^{13} \mathrm{CO}_{2}$ labelling and PTR-MS analysis, Plant, Cell Environ., 33, 781-792, 2010.

Guenther, A., Hewitt, C. N., Erickson, D., Fall, R., Geron, C., Graedel, T., Harley, P., Klinger, L., Lerdau, M., Mckay, W.A., Pierce, T., Scholes, B., Steinbrecher, R., Tallamraju, R., Taylor, J., and Zimmerman, P.: A global-model of natural volatile organic compound emissions, J. Geophys. Res., 100, 8873-8892, 1995.

Guenther, A. B., Zimmerman, P. R., Harley, P. C., Monson, R. K., and Fall, R.: Isoprene and monoterpene emission rate variability - Model evaluations and sensitivity analyses, J. Geophys. Res., 98, 12609-12617, 1993. 
Hakola, H., Laurila, T., Rinne, J., and Puhto, K.: The ambient concentrations of biogenic hydrocarbons at a Northern European, boreal site, Atmos. Environ., 34, 4971-4982, 2000.

Hakola, H., Tarvainen, V., Bäck, J., Ranta, H., Bonn, B., Rinne, J., and Kulmala, M.: Seasonal variation of mono- and sesquiterpene emission rates of Scots pine, Biogeosciences, 3, 93-101, doi:10.5194/bg-3-93-2006, 2006.

Helmig, D., Ortega, J., Duhl, T., Tanner, D., Guenther, A., Harley, P., Wiedinmyer, C., Milford, J., and Sakulyanontvittaya, T.: Sesquiterpene Emissions from Pine Trees - Identifications, Emission Rates and Flux Estimates for the Contiguous United States, Environ. Sci. Technol., 41, 1545-1553, 2007.

lvesniemi, H., Levula, J., Ojansuu, R., Kolari, P., Kulmala, L., Pumpanen, J., Launiainen, S., Vesala, T., and Nikinmaa, E.: Long-term measurements of the carbon balance of a boreal Scots pine dominated forest ecosystem, Boreal Environ. Res., 14, 731$753,2009$.

Janson, R.: Monoterpene emissions from Scots Pine and Norwegian Spruce, J. Geophys. Res., 98, 2839-2850, 1993.

Janson, R. and De Serves, C.: Acetone and monoterpene emissions from the boreal forest in northern Europe, Atmos. Environ., 35, 4629-4637, 2001.

Jardine, K., Yañez Serrano, A., Arneth, A., Abrell, L., Jardine, A., van Haren, J., Artaxo, P., Rizzo, L. V., Ishida, F. Y., Karl, T., Kesselmeier, J., Saleska, S., and Huxman, T.: Within-canopy sesquiterpene ozonolysis in Amazonia, J. Geophys. Res., 116, D19301, doi:10.1029/2011JD016243, 2011.

Kaplan, J. O., Folberth, G., and Hauglustaine, D. A.: Role of methane and biogenic volatile organic compound sources in late glacial and Holocene fluctuations of atmospheric methane concentrations, Global Biogeochem. Cy., 20, GB2016, doi:10.1029/2005GB002590, 2006.

Komenda, M. and Koppmann, R.: Monoterpene emissions from Scots pine (Pinus sylvestris): Field studies ofemission rate variabilities, J. Geophys. Res., 107, 4161, doi:10.1029/2001JD000691, 2002.

Komenda, M., Kobel, K., Koppmann, R., and Wildt, J.: Comparability of biogenic VOC emission rate measurements under laboratory and ambient conditions at the example of monoterpene emissions from Scots pine (Pinus sylvestris), J. Atmos. Chem., 45, 1-23, 2003.

Kulmala, M., Vehkamäki, H., Petäjä, T., Dal Maso, M., Lauri, A., Kerminen, V.-M., Birmili, W., and McMurry, P. H.: Formation and growth rates of ultrafine atmospheric particles: A review of observations, J. Aerosol Sci., 35, 143-176, 2004.

Li, Z., Ratliff, E. A., and Sharkey, T. D.: Effect of temperature on postillumination isoprene emission in oak and poplar, Plant Physiol., 155, 1037-1046, 2011.

Lindfors, V. and Laurila, T. : Biogenic volatile organic compound (VOC) emissions from forests in Finland, Boreal Environ. Res., 5, 95-113, 2000.

Lindfors, V., Laurila, T., Hakola, H., Steinbrecher, R., and Rinne, J.: Modeling speciated terpenoid emissions from the European boreal forest. Atmos. Environ., 34, 4983-4996, 2000.

Loreto, F., Förster, A., Durr, M., Csiky, O., and Seufert, G.: On the monoterpene emission under heat stress and on the increased thermotolerance of leaves of Quercus ilex L. fumigated with selected monoterpenes, Plant Cell Environ., 21, 101-107, 1998.
Martin, D., Tholl, D., Gershenzon, J., and Bohlmann, J.: Methyl jasmonate induces traumatic resin ducts, terpenoid resin biosynthesis, and terpenoid accumulation in developing xylem of Norway spruce stems, Plant Physiol., 129, 1-16, 2002.

Mogensen, D., Smolander, S., Sogachev, A., Zhou, L., Sinha, V., Guenther, A., Williams, J., Nieminen, T., Kajos, M. K., Rinne, J., Kulmala, M., and Boy, M.: Modelling atmospheric OH-reactivity in a boreal forest ecosystem, Atmos. Chem. Phys., 11, 97099719, doi:10.5194/acp-11-9709-2011, 2011.

Monson, R., Hills, A. J., Zimmerman, P. R., and Fall, R. R.: Studies of the relationship between isoprene emission rate and $\mathrm{CO}_{2}$ or photon-flux density using a real-time isoprene analyser, Plant, Cell Environ., 14, 517-523, 1991.

Nölscher, A. C., Williams, J., Sinha, V., Custer, T., Song, W., Johnson, A. M., Axinte, R., Bozem, H., Fischer, H., Pouvesle, N., Phillips, G., Crowley, J. N., Rantala, P. Rinne, J. Kulmala, M., Gonzales, D., Valverde-Canossa, J., Vogel, A., Hoffmann, T. , Ouwersloot, H. G., Vilá-Guerau de Arellano, J., and Lelieveld, J.: Summertime total $\mathrm{OH}$ reactivity measurements from boreal forest during HUMPPA-COPEC 2010, Atmos. Chem. Phys. Discuss., 12, 7419-7452, 2012, doi:10.5194/acpd-12-7419-2012, 2012.

Persson, M., Borgkarlson, A. K., and Norin, T.: Enantiomeric composition of 6 chiral monoterpene hydrocarbons in different tissues of Pica-Abies, Phytochem., 33, 303-307, 1993.

Pollmann, J., Ortega, J., and Helmig, D.: Analysis of atmospheric sesquiterpenes: sampling losses and mitigation of ozone interference, Environ. Sci. Technol., 39, 9620-9629, 2005.

Rinne, J., Taipale, R., Markkanen, T., Ruuskanen, T. M., Hellén, H., Kajos, M. K., Vesala, T., and Kulmala, M.: Hydrocarbon fluxes above a Scots pine forest canopy: measurements and modeling, Atmos. Chem. Phys., 7, 3361-3372, doi:10.5194/acp-73361-2007, 2007.

Rinne, J., Hakola, H., and Laurila, T.: Vertical fluxes of monoterpenes above a Scots pine stand in the boreal vegetation zone, Phys. Chem. Earth, 24, 711-715, 1999.

Rinne, J., Hakola, H., Laurila, T., and Rannik, Ü.: Canopy scale monoterpene emissions of Pinussylvestris dominated forests, Atmos. Environ., 34, 1099-1107, 2000.

Shao, M., Czapiewski, K. V., Heiden, A. C., Kobel, K., Komenda, M., Koppman, R., and Wildt, J.: Volatile organic compound emissions from Scots pine: Mechanisms and description by algorithms, J. Geophys. Res., 106, 20483-20491, 2001.

Singsaas, E. L., Lerdau, M., Winter, K., and Sharkey, T. D.: Isoprene increases thermotolerance of isoprene-emitting species, Plant Physiol., 115, 1413-1420, 1997.

Song, W., Williams, J., Yassaa, N., Martinez, M., Adame, J. A., Hidalgo, P. J., Bozem, H., and Lelieveld, J.: Winter and summer characterization of biogenic enantiomeric monoterpenes and anthropogenic BTEX compounds at a Mediterranean Stone Pine forest site, J. Atmos. Chem., J. Atmos. Chem., 68, 233-250, 2011.

Staudt, M. and Lhoutellier, L.: Monoterpene and sesquiterpene emissions from Quercus coccifera exhibit interacting responses to light and temperature, Biogeosciences, 8, 2757-2771, doi:10.5194/bg-8-2757-2011, 2011.

Stokes, G. Y., Chen, E. H., Buchbinder, A. M., Paxton, W. F., Keeley, A., and Geiger, F. M., Atmospheric Heterogeneous stereochemistry. J. Am. Chem. Soc., 131, 13733-13737, 
doi:10.1021/ja904206t, 2009.

Thoss, V., O'Reilly-Wapstra, J., and Iason, G. R.: Assessment and Implications of Intraspecific and Phenological Variability in Monoterpenes of Scots Pine (Pinus sylvestris) Foliage, J. Chem. Ecol., 33, 477-491, 2007.

Tumlinson J. H.: Contemporary frontiers in insect semiochemical research, J. Chem. Ecol., 14, 2109-2130, 1988.

Tunved, P., Hansson, H. C., Kerminen, V. M., J. Ström, Dal Maso, M., Lihavainen, H., Viisanen, Y., Aalto, P. P., Komppula, M., and Kulmala, M.: High natural aerosol loading over boreal forests, Science, 312, 261-263, 2006.

Williams, J.: Organic trace gases: An overview, Environ. Chem., 1, 125-136, 2004.

Williams, J., Yassaa, N., Bartenbach, S., and Lelieveld, J.: Mirror image hydrocarbons from Tropical and Boreal forests, Atmos. Chem. Phys., 7, 973-980, doi:10.5194/acp-7-973-2007, 2007.

Williams, J., Crowley, J., Fischer, H., Harder, H., Martinez, M., Petäjä, T., Rinne, J., Bäck, J., Boy, M., Dal Maso, M., Hakala, J., Kajos, M., Keronen, P., Rantala, P., Aalto, J., Aaltonen, H., Paatero, J., Vesala, T., Hakola, H., Levula, J., Pohja, T., Herrmann, F., Auld, J., Mesarchaki, E., Song, W., Yassaa, N., Nölscher, A., Johnson, A. M., Custer, T., Sinha, V., Thieser, J., Pouvesle, N., Taraborrelli, D., Tang, M. J., Bozem, H., Hosaynali-Beygi, Z., Axinte, R., Oswald, R., Novelli, A., Kubistin, D., Hens, K., Javed, U., Trawny, K., Breitenberger, C., Hidalgo, P. J., Ebben, C. J., Geiger, F. M., Corrigan, A. L., Russell, L. M., Ouwersloot, H. G., Vilà-Guerau de Arellano, J., Ganzeveld, L., Vogel, A., Beck, M., Bayerle, A., Kampf, C. J., Bertelmann, M., Köllner, F., Hoffmann, T., Valverde, J., González, D., Riekkola, M.-L., Kulmala, M., and Lelieveld, J.: The summertime Boreal forest field measurement intensive (HUMPPA-COPEC-2010): an overview of meteorological and chemical influences, Atmos. Chem. Phys., 11, 10599-10618, doi:10.5194/acp-11-10599-2011, 2011.
Yassaa, N., Brancaleoni, E., Frattoni, M., and Ciccioli, P.: Trace level determination of enantiomericmonoterpenes in terrestrial plant emission and in the atmosphere using a $\beta$-cyclodextrin capillary column coupled with thermal desorption and mass spectrometry, J. Chromatogr. A, 915, 185-197, 2001.

Yassaa, N. and Williams, J.: Analysis of enantiomeric and nonenantiomeric monoterpenes in plant emissions using portable dynamic air sampling/solid-phase microextraction (PDAS-SPME) and chiral gas chromatography/mass spectrometry, Atmos. Environ., 39, 4875-4884, 2005.

Yassaa, N. and Williams, J.: Enantiomeric monoterpene emissions from natural and damaged Scots pine in a boreal coniferous forest measured using solid-phase microextraction and gas chromatography/mass spectrometry, J. Chromatogr. A, 1141, 138144, 2007.

Yassaa, N., Custer, T., Song, W., Pech, F., Kesselmeier, J., and Williams, J.: Quantitative and enantioselective analysis of monoterpenes from plant chambers and in ambient air using SPME, Atmos. Meas. Tech., 3, 1615-1627, doi:10.5194/amt-31615-2010, 2010. 